\title{
INTEGRATION PROSPECT OF THE TURKISH INSURANCE MARKET WITH THE EUROPEAN SINGLE INSURANCE MARKET: A SURVEY AMONG TURKISH MARKET PLAYERS
}

\section{Onur Acar*}

\section{Abstract}

The main aim of this paper is to analyze the extent of the harmonization of the Turkish insurance market with the European single insurance market and the integration prospect between the two markets. The results revealed that even though consumers and re/insurers situated in any one of the Member States are completely free to operate throughout the European Economic Area (EEA) under the same conditions with local companies and consumers, insurers do not make use of freedom of services (FOS) and freedom of establishment (FOE) and thus insurance markets of the EEA Member States are still far from being integrated markets. Mergers and acquisitions are still the dominant strategy to access a foreign insurance market in the EEA. As far as the Turkish insurance market is concerned, it is argued that Turkey, an acceding country to the EU, harmonized its insurance legislation with the EU insurance acquis to a great extent. Perceptions and expectations of the Turkish insurance market on the current level of harmonization and the integration prospect with the European single insurance market are investigated by a survey. The sector believes that Turkish insurance legislation is already harmonized with the EU insurance acquis and that the EU membership of Turkey would be beneficial for the Turkish insurance market but as of today it would not result in the integration of the market with the insurance markets of the EEA Member States.

\footnotetext{
*Ph.D, Marmara University, EU Institute, e-mail: onacar@hotmail.com
}

Bu makale, Marmara Üniversitesi AB Enstitüsü'nde başarılı bir şekilde sunulup onaylanan doktora tezinin genişletilmiş bir özetidir. 
Keywords: Insurance, Integration, Turkish Insurance Market, European Single Insurance Market

\section{Özet}

Bu çalışmanın temel amacı, Türk sigorta piyasasının Avrupa tek sigorta piyasaslyla mevcut uyum duzeyini ve bu iki piyasa arasindaki entegrasyon olasılığını araştırmaktır. Çalışmanın sonuçları, tüm AEA üyesi ülkelerdeki tüketicilerin ve sigorta/reasürans şirketlerinin eşit şartlarda faaliyet göstermesine karşın, sigorta piyasası göstergelerinin birbiriyle yakınsamadiğ , sigorta şirketlerinin hizmetlerin serbest sunumu ve yerleşme serbestisinden yararlanmadiğ ve sigorta piyasalarinin entegre olmaktan henüz oldukça uzak olduğunu göstermektedir. AEA'da yabancı sigorta piyasalarına girmek için kullanılan esas yöntem hala birleşme ve satın almalardır. Bu çalışmada Türk sigorta sektörüne ilişkin olarak ise, AB ile üyelik müzakerelerine devam eden Türkiye'nin sigorta mevzuatın $A B$ sigorta müktesebatryla büyük ölçüde uyumlu hale getirdiği sonucuna varılmıştır. Türk sigorta sektörünün Avrupa tek sigorta piyasasiyla uyum seviyesine ve entegrasyon olasılığına ilişkin algllar ve beklentileri ise anket yöntemiyle araştırılmıştır. Buna göre, sigorta sektörü, Türk sigorta mevzuatının AB sigorta müktesebatıyla hali hazırda uyumlu hale geldiğini ve Türkiye'nin $A B$ üyeliğinin Türk sigorta piyasasına faydalı olacağını, ancak bugun itibariyla üyeliğin AB sigorta piyasalartyla entegrasyona yol açmayacă̆ını düşünmektedir.

Anahtar Kelimeler: Sigorta, Entegrasyon, Türk Sigorta Piyasast, Avrupa Tek Sigorta Piyasası

\section{Introduction}

There has been an increase in the level of international financial integration over the last two decades. Like other financial markets, an integrated insurance market contributes to the economic growth and thus increases the welfare of the citizens. It may also have important implications on the insurers such as improved diversification, increased economies of scale and higher competitive power and on the consumers such as larger choice of products and higher protection. Therefore, the degree of insurance markets integration merits investigation. 
Insurance market in Turkey is a young, dynamic and promising market which has been growing steadily in recent years with increasing premium production and foreign investments. It is in a process of harmonization with the EU insurance acquis and has a big growth potential. It is generally accepted that insurance legislation in Turkey has been aligned with the EU insurance legislation to a great extent. However, to our best knowledge, there is no study which investigates the perceptions and expectations on the integration process of the Turkish insurance market with the European single insurance market.

This paper tries to shed additional light on the perceptions of the managers in the Turkish insurance market on the level of harmonization of the Turkish insurance market with the European single insurance market. It also aims to show their expectations on the integration prospect between the two markets. It first presents briefly the level of integration of the insurance markets of the EEA Member States by using quantity-based indicators and the level of harmonization between the Turkish insurance market and the European single insurance market. Then, expectations of the managers on the level of harmonization of the Turkish insurance market with the European single insurance market as well as their perceptions and expectations on the integration prospect between the two markets are investigated by a survey. Descriptive and inferential analyses are conducted in order to identify and interpret the results of the survey.

\section{A Preface to the Survey}

European single insurance market is a market where both insurance companies and consumers are free to operate and buy insurance products anywhere in the single market, under the same conditions with local companies and consumers. It covers the Member States of the European Economic Area (EEA) which is actually composed of the 27 Member States of the EU and three of the four Member States of the EFTA, namely Norway, Liechtenstein and Iceland which take part of the EU's internal market.

Brittan (1990: 413) points out that to establish a single insurance market in the EU, insurance and reinsurance companies situated in any one of the Member States must be completely free to operate throughout the EU, either through freedom of establishment (FOE) or through freedom of services (FOS). FOE means the right for any insurance company having its head 
office in one of the EU Member States to carry out insurance business in other Member States by setting up a branch, an agency or an office managed by the company's own staff. FOS means the right for an insurance company the right to sell their products across national frontiers without prior authorization from the host Member State's regulatory authority and without having to set up an establishment there (Ellis, 1990: 11).

While late and/or wrong transposition and wrong implementation of directives persist, the EU insurance legislation is almost completed in creating FOS and FOE through three generation of insurance directives. ${ }^{1}$ Since there is no more discrimination between foreign and domestic market players, it is generally accepted that from the legislative point of view, the EU insurance markets, together with those of Liechtenstein, Norway and Iceland, became a single insurance market since the entry into force of the third generation of life and non-life insurance directives in 1994.

However, quantity based indicators do not show any sign of integration in the European single insurance market. Neither foreign presence through direct cross-border sales without physical establishment nor foreign presence through locally established branches and agencies exist in the single market. Weidenfeld (1996: 104) claims that insurers use freedom of services as an easy way of testing the marketability of their products in case of future establishment in that Member States through branches or subsidiaries. FOS is used temporarily by large European insurance groups before establishing in the other EEA insurance markets and the ultimate aim is physical establishment in the Member State where they wish to operate. The use of FOS in life business is higher than in non-life business. Following the Skipper (1997: 2) classification of direct cross-border insurance trade, cross-border insurance is used for large commercial and industrial risks in wholesale insurance markets in the form of pure or owninitiative cross-border insurance. The volume of cross-border retail business

\footnotetext{
${ }^{1}$ First Council Directives 73/239/EEC for non-life insurance and 79/267/EEC for life insurance

Second Council Directives 88/357/EEC for non-life insurance and 90/619/EEC for life insurance

Third Council Directives 92/49/EEC for non-life insurance and 92/96/EEC for life insurance
} 
is negligible. It mostly concerns people living in border areas and expatriates in the form of consumption-abroad cross-border insurance.

Cross-border activities through FOE are also restricted in the European single insurance market. Beckmann, et al. (2002: 9) find that in 1997 the share of non-life branches was $1,8 \%$ and the share of life branches was $0,18 \%$. The weighted average of the premiums written in the EEA through FOE have a share of $2,9 \%$ in total EEA premium production in 2008. Therefore, although it is still very limited, there is an increasing trend in the use of FOE in the European single insurance market. Labilloy (2003: 39) reports that between two-thirds and three-quarters of branches of the EEA insurance companies are established in a Member State neighboring to the State in which they have their head offices. The use of FOE in non-life business is higher than in life business. Furthermore, branching is smaller in retail business than in wholesale business.

The preferred method of foreign market entry in the EEA is physical establishment in the host Member State. Since the insurance business requires a high degree of consultancy, credibility and client confidence, local customers are likely to be suspicious of a foreign insurer which does not have a local office (Hess and Trauth, 1998: 95). However, the physical establishment is not done through FOE since foreign insurers normally lack the experience to cope with a different insurance contract law and the understanding of local market conditions and preferences. Acquisition of local insurers is still the dominant strategy of the EEA insurers to access the other EEA insurance markets, rather than setting up new structures and new teams in those markets. It has the advantage of gaining the necessary knowhow about the domestic market conditions and consumer preferences as well as the access to local distribution channels.

Foreign presence through merger with or acquisition of domestic insurers shows that competition takes place on a multi-domestic basis with cross-border entities where customers are confined to their national markets dominated by few large European insurance groups (European Commission, 2007: 44). Therefore, while the aim of the insurance regulation at the EU level has been to create a framework for an integrated insurance market, deregulation has not led to considerable expansion in cross-border insurance trade but has rather led to an unprecedented wave of M\&As. 
As to the integration of the Turkish insurance market with the EEA insurance markets, there is no FOE or FOS between these markets since Turkey is not a member of the EEA. One way to analyze the integration prospect of the Turkish insurance market with the European single insurance market is to evaluate the existing regulatory and supervisory differences between these two markets. Higher level of legislative harmonization predicts higher potential for integration. The level of harmonization for each topic is shown below:

- $\quad$ As to the taking up and pursuit of insurance and reinsurance business in Turkey, there is no discrimination between domestic and foreign insurance companies and branches.

- Foreign agents operating in Turkey are subject to the same rules required for insurance agents established in Turkey.

- $\quad$ There is no reinsurance monopoly.

- $\quad$ Licensing requirements for the insurers such as obtaining license for each branch, presentation of a business plan, showing evidence of compliance with the system of governance, holding adequate own funds, fit and proper criteria for founders and managers and taking-up capital for each branch are in line with the EU acquis.

- Tariff liberalization is at an advanced stage except the tariffs in compulsory insurances. Tariffs in MTPL insurance are liberalized to a great extent but minimum limits of coverage should still be further increased.

- Calculation of technical reserves, the rules on the assets covering the technical reserves, content of financial statements, auditing of the financial statements by independent audit firms, financial reporting standards and calculation of capital requirements are largely in line with the EU acquis. However, deposit system in life insurance should be abolished.

In line with the EU principle of effective policyholder protection, policyholders are well informed both before and during the contractual period. Necessary institutions for better policyholder protection such as Assurance Account and Arbitration Commission are established. However, Assurance Account is liable only for personal injuries and its scope should be broadened to cover damages to property. 
The comparative analysis reveals the fact that the Turkish insurance legislation is harmonized with the EU insurance acquis to a great extent whereas further alignment efforts such as the liberalization of tariff system in compulsory insurances, removal of the approval of general conditions, removal of the deposit system in life insurance, amendment on the scope and limits of MTPL insurance coverage and adoption of specific legislation on reinsurance and supervision of insurance groups are required.

Progress Reports that are published each year by the EU for each candidate country to monitor and assess the achievements of the candidates recognize also the improvement in the harmonization level of the Turkish insurance sector. Compared to the previous Turkey Regular Reports which state that the overall alignment of Turkish insurance legislation with the EU insurance acquis is "limited", in the 2007 Regular Report it is stated for the first time that the alignment with the acquis is "partial".

Foreign insurers widely operate in Turkish life and non-life insurance markets. The share of foreign paid-in capital to total paid-in capital of the Turkish insurance market reached 55\% in life and non-life business in 2009 (ISB, 2009:13). Whereas opening of the EU membership negotiations in 2005 has an effect on the acceleration of foreign penetration into the Turkish insurance market, at micro-level growth potential and profitability opportunities and at macro-level young population, macro-economic results and political stability are the main motivations behind the interest of the EEA insurers. A survey carried out by the European Commission on the insurers that had entered the market of another EU Member State concluded also that the main drivers of the EU insurers to enter another market are purely commercial such as potential for growth or profitability (European Commission, 2007: 48).

Whereas the insurers operating in Turkey are not benefiting from FOS and FOE, majority of the foreign insurers operating in the Turkish insurance market are EEA-based insurers which are established in Turkey through M\&A. It reflects the fact that the EU insurers are widely operating in the Turkish insurance market without feeling the need to wait for the membership of Turkey to the EU. However, the level of integration between

${ }^{2}$ See Turkey 2007 Progress Report, European Commission, COM (2007) 663 final, Brussels, 6.11.2007 
the Turkish insurance market and the European single insurance market after the membership of Turkey to the EU cannot be quantified since there has not yet been FOS or FOE between the two markets.

Therefore, perceptions and expectations of the Turkish insurance market (1) on the current harmonization level of the Turkish insurance market with the European single insurance market, (2) on the benefits and costs of the EU membership of Turkey in Turkish insurance market and (3) on the integration prospect between the two markets are investigated by a survey covered 52 managers from 33 different companies.

\section{Aim of the Survey}

The main aim of the survey is to explore the perceptions and expectations of the managers in the Turkish insurance sector about the integration of the Turkish insurance market to the European single insurance market. Perceptions and expectations on the current harmonization level of the Turkish insurance market with the European single insurance market, on the benefits and costs of the EU membership of Turkey in Turkish insurance market and on the integration level between the two markets when Turkey becomes member of the EU are investigated in the survey.

The following questions are investigated by three different scales which measure the belief in the level of harmonization, in the benefits of the EU membership of Turkey and in the level of integration as a result of the membership of Turkey to the EU:

- Perceptions on the level of harmonization of the Turkish insurance legislation with the EU insurance acquis

- Perceptions on the existence of harmonization in different areas of legislation related to insurance

- Perceptions on behavioral changes of insurers and consumers during the harmonization process

- $\quad$ Expectations on the benefits of the membership of Turkey to the EU in the Turkish insurance market

- Expectations on the likelihood of different types of benefits and costs occurring in the Turkish insurance market when Turkey becomes member of the EU 
- Expectations on the level of integration between the Turkish insurance market and European single insurance market when Turkey becomes member of the EU

- Expectations on the market entry strategies of the EU insurers to operate in Turkey and Turkish insurers to operate in the EU when Turkey becomes member of the EU

- Expectations on the likelihood of different insurance branches in which the EU insurers would intend to operate in Turkey when Turkey becomes member of the EU

- Expectations on types of consumers who would buy insurance products from the insurers established in the EU when Turkey becomes member of the EU

The questions of the survey are tested in order to see whether there is a significant relationship between foreign and domestic insurers and between life and non-life insurers. The existence of a significant difference between foreign and domestic insurers and between life and non-life insurers in their belief in the level of harmonization of the Turkish insurance market with the European single insurance market, in their belief in the benefits of the integration of Turkish insurance market with the European single insurance market when Turkey becomes member of the EU and in their belief in the level of integration between Turkish insurance market and European single insurance market when Turkey becomes member of the EU are investigated.

\section{Methodology of the Survey}

\subsection{Participants}

The survey covered 52 managers from 33 different companies. This corresponds around $17 \%$ of all top managers and $58 \%$ of all companies in the market. The distribution of the participants is shown in Table 1. Companies having more than $50 \%$ of their equity acquired by foreigners are classified as foreign companies. 22 participants from domestic companies and 30 participants from foreign companies operating in Turkey participated in the survey. 18 participants are from life insurance companies ( 7 of them being from domestic companies and the remaining 11 being from foreign companies), 29 participants are from non-life insurance companies (10 of them being from domestic companies and the remaining 19 being from 
foreign companies), 3 participants are from reinsurance companies and 2 participants are from insurance professional organizations.

Table 1: Number of Participants

\begin{tabular}{|l|c|c|c|}
\hline & domestic & foreign & total \\
\hline life & 7 & 11 & $\mathbf{1 8}$ \\
\hline non-life & 10 & 19 & $\mathbf{2 9}$ \\
\hline other & 5 & - & $\mathbf{5}$ \\
\hline total & $\mathbf{2 2}$ & $\mathbf{3 0}$ & $\mathbf{5 2}$ \\
\hline
\end{tabular}

Source: Table composed by the author

The first 10 non-life companies writing $73 \%$ of the total non-life premium production and the first 5 life companies writing $67 \%$ of the total life premium production are considered as big companies. As a result, for the purpose of this study, 30 participants are from the companies labeled as big companies and 20 participants are from the companies labeled as small companies.

\subsection{Instruments}

The scale used in this survey to measure the belief in the level of harmonization consists of 19 items covering relevant areas of insurance legislation and participants are asked to indicate the degree to which they believe that the harmonization exists. They give their responses on a 5-point Likert scale ranging from 1 (strongly disagree) to 5 (strongly agree) with higher scores indicating greater belief in the existence of harmonization. Items affirming the lack of harmonization are reverse scored.

The scale used to measure the belief in the benefits in Turkish insurance market when Turkey becomes member of the EU covers 21 items containing different types of benefits and costs. The participants are asked to indicate the degree to which they expect that there will be benefits for the Turkish insurance market when Turkey becomes member of the EU. They give their responses on a 5-point Likert scale ranging from 1 (strongly disagree) to 5 (strongly agree) with higher scores indicating greater belief in the benefits of membership. Items affirming the costs of membership are reverse scored. 
The scale used to measure the belief in the level of integration when Turkey becomes member of the EU consists of 12 items covering different types of foreign market entry strategies. The participants are asked to indicate their degree of expectations related to the foreign market entry strategies of the EU and Turkish insurers when Turkey becomes member of the EU. They give their responses on a 5-point Likert scale ranging from 1 (strongly disagree) to 5 (strongly agree) with higher scores indicating greater belief in the materialization of integration. Items affirming foreign market entry strategies without need for integration are reverse scored.

In addition, participants are asked to give the name of the company they work for so that they can be categorized in terms of type and nationality of company. All of the respondents surveyed are guaranteed complete anonymity when the results are evaluated and published.

\subsection{Exploratory Data Analysis}

Exploratory Data Analysis (EDA) is performed to reveal possible errors in the data, to test for normality and homogeneity and then to determine whether parametric or non-parametric tests should be used.

First of all, reliability is checked for all scales. It is measured with Cronbach's alpha. The reliabilities of the scales used to measure dependent variables are reported in Table 2. An alpha between .6 and .8 indicates acceptable reliability and an alpha of .8 or higher indicates good reliability. Therefore, Cronbach's alphas turned out to be acceptable for all scales of the survey.

Table 2: Results of Reliability Test

\begin{tabular}{|c|c|c|}
\hline Variable & $\begin{array}{c}\text { number of } \\
\text { items }\end{array}$ & $\begin{array}{c}\text { Cronbach's } \\
\text { alpha }\end{array}$ \\
\hline Harmonization & 19 & .61 \\
\hline Benefits & 21 & .78 \\
\hline Integration & 12 & .75 \\
\hline
\end{tabular}

Source: own Table based on the results of reliability test run in SPSS

Then, normality tests are performed to investigate if variables are normally distributed for each level of the independent variable. In order to determine normality, graphical and numerical methods are used. The 
distribution of all variables is graphically compared to a standard normal distribution by using Q-Q plots. In each graph, the points in the Q-Q plot lie approximately in a straight line. Therefore, the data is from normally distributed population.

As a numerical method of assessing normality, Shapiro-Wilk Test which is appropriate for small samples which are less than 2000 participants is performed. The results of Shapiro-Wilk Test are presented in Table 3 . The null hypothesis that the data comes from a normally distributed population cannot be rejected for none of the variables since $p>.005$ in each case. Therefore, for domestic and foreign companies and for life and non-life companies, dependent variables are normally distributed.

Table 3: Results of Shapiro-Wilk Test of Normality

\begin{tabular}{|c|l|c|c|}
\hline $\begin{array}{c}\text { Dependent } \\
\text { variable }\end{array}$ & $\begin{array}{l}\text { Independent } \\
\text { variable }\end{array}$ & Statistic & Sig. \\
\hline \multirow{4}{*}{ Harmonization } & Domestic & .90 & .06 \\
\cline { 2 - 4 } & Foreign & .96 & .32 \\
\cline { 2 - 4 } & Life & .97 & .80 \\
\cline { 2 - 4 } & non-life & .93 & .09 \\
\hline \multirow{4}{*}{ Benefits } & Domestic & .95 & .32 \\
\cline { 2 - 4 } & Foreign & .97 & .61 \\
\cline { 2 - 4 } & Life & .93 & .24 \\
\cline { 2 - 4 } & non-life & .96 & .36 \\
\hline \multirow{5}{*}{ Integration } & Domestic & .96 & .53 \\
\cline { 2 - 4 } & Foreign & .96 & .51 \\
\cline { 2 - 4 } & Life & .93 & .20 \\
\cline { 2 - 4 } & non-life & .96 & .37 \\
\hline
\end{tabular}

Source: own Table based on the results of Shapiro-Wilk Tests run in SPSS

Homogeneity of the variances is tested to see whether the variances of the observations in the individual groups are equal. Levene's Test of Equality of Error Variances is performed to check the homogeneity of variance. The results of Levene's Test are shown in Table 4. The null hypothesis that the population variances are equal cannot be rejected for 
none of the variables since $\mathrm{p}>.005$ in each case. Therefore, the error variance of each dependent variable is equal across groups.

Table 4: Results of Levene's Test of Homogeneity

\begin{tabular}{|c|c|c|c|}
\hline Dependent variable & $\begin{array}{c}\text { Independent } \\
\text { variable }\end{array}$ & F & Sig. \\
\hline \multirow{2}{*}{ Harmonization } & domestic/foreign & .13 & .71 \\
\cline { 2 - 4 } & life/non-life & .72 & .54 \\
\hline \multirow{2}{*}{ Benefits } & domestic/foreign & 3.41 & .07 \\
\cline { 2 - 4 } & life/non-life & 3.11 & .06 \\
\hline \multirow{2}{*}{ Integration } & domestic/foreign & 1.948 & .16 \\
\cline { 2 - 4 } & life/non-life & 1.277 & .29 \\
\hline
\end{tabular}

Source: own Table based on the results of Levene's Tests run in SPSS

\section{Results of the Survey}

Descriptive statistics on all variables are reported in Table 5. The perception of the respondents on the harmonization level is that Turkish insurance legislation is harmonized with the EU insurance acquis $(M=$ 3.65; $S D=.27)$. The perception of the sector is in conformity with the finding of the comparative analysis made in this study on insurance legislation of Turkey and the EU that although there are still areas to be further harmonized, Turkish insurance legislation is harmonized with the EU insurance acquis to a great extent.

Respondents expect that the membership of Turkey to the EU would be beneficial for the Turkish insurance market $(M=3.48 ; S D=.35)$. Interestingly enough, both big and small insurers expect that the benefits of being member of the EU will be higher than its costs. It can be concluded that they would not abstain from further harmonization with the EU insurance acquis.

Furthermore, as to the level of integration between the insurance markets of the current EU Member States and Turkey as a result of the membership of Turkey to the EU, the expectation of the respondents is not as strong as the previous two tendencies $(M=2.99 ; S D=.47)$. The sector does not seem strongly optimistic about the realization of the integration. 
Moreover, the expectations on the realization of integration differ within the sector.

Table 5: Descriptive Statistics of Variables

\begin{tabular}{|c|c|c|c|c|c|c|c|}
\hline \multirow[t]{2}{*}{ variables } & $\begin{array}{l}\text { Total } \\
\text { Sample }\end{array}$ & $\begin{array}{l}\text { Sample } \\
\text { of } \\
\text { Domestic } \\
\text { Insurers }\end{array}$ & $\begin{array}{l}\text { Sample } \\
\text { of } \\
\text { Foreign } \\
\text { Insurers }\end{array}$ & $\begin{array}{l}\text { Sample } \\
\text { of Life } \\
\text { Insurers }\end{array}$ & $\begin{array}{l}\text { Sample } \\
\text { of Non- } \\
\text { life } \\
\text { Insurers }\end{array}$ & $\begin{array}{l}\text { Sample } \\
\text { of Big } \\
\text { Insurers }\end{array}$ & $\begin{array}{l}\text { Sample } \\
\text { of Small } \\
\text { Insurers }\end{array}$ \\
\hline & $\begin{array}{l}\text { Mean } \\
\text { (SD) }\end{array}$ & $\begin{array}{l}\text { Mean } \\
\text { (SD) }\end{array}$ & $\begin{array}{l}\text { Mean } \\
\text { (SD) }\end{array}$ & $\begin{array}{l}\text { Mean } \\
\text { (SD) }\end{array}$ & $\begin{array}{l}\text { Mean } \\
\text { (SD) }\end{array}$ & $\begin{array}{l}\text { Mean } \\
\text { (SD) }\end{array}$ & $\begin{array}{l}\text { Mean } \\
\text { (SD) }\end{array}$ \\
\hline harmonization & $\begin{array}{l}3.65 \\
(.27)\end{array}$ & $3.63(.31)$ & $\begin{array}{l}3.66 \\
(.24)\end{array}$ & $\begin{array}{l}3.64 \\
(.23)\end{array}$ & $\begin{array}{l}3.65 \\
(.31)\end{array}$ & $\begin{array}{l}3.62 \\
(.27)\end{array}$ & $\begin{array}{l}3.67 \\
(.28)\end{array}$ \\
\hline benefit & $\begin{array}{l}3.48 \\
(.35)\end{array}$ & $3.37(.37)$ & $\begin{array}{l}3.57 \\
(.31)\end{array}$ & $\begin{array}{l}3.46 \\
(.20)\end{array}$ & $\begin{array}{l}3.57 \\
(.37)\end{array}$ & $\begin{array}{l}3.50 \\
(.38)\end{array}$ & $\begin{array}{l}3.50 \\
(.29)\end{array}$ \\
\hline integration & $\begin{array}{l}2.99 \\
(.47)\end{array}$ & $2.80(.35)$ & $\begin{array}{l}3.18 \\
(.49)\end{array}$ & $\begin{array}{l}2.92 \\
(.56)\end{array}$ & $\begin{array}{l}3.11 \\
(.44)\end{array}$ & $\begin{array}{l}2.97 \\
(.48)\end{array}$ & $\begin{array}{l}3.09 \\
(.49)\end{array}$ \\
\hline
\end{tabular}

Source: own Table based on the results of the survey

Since reliability of the scales used in the survey is acceptable, data is normally distributed and variances are identical, the assumptions to run analysis of variance (ANOVA), a parametric test, are validated. Therefore, the existence of a significant difference between foreign and domestic insurers and between life and non-life insurers in their belief in the level of harmonization, in the benefits of the integration and in the level of integration is tested by one-way ANOVA. The results of ANOVA for all variables are reported in Table 6.

Table 6: Results of ANOVA

\begin{tabular}{|c|c|c|c|}
\hline $\begin{array}{c}\text { Dependent } \\
\text { variable }\end{array}$ & $\begin{array}{c}\text { Independent } \\
\text { variable }\end{array}$ & F & Sig. \\
\hline \multirow{2}{*}{ Harmonization } & domestic/foreign & .08 & .77 \\
\cline { 2 - 4 } & life/non-life & .43 & .72 \\
\hline \multirow{2}{*}{ Benefits } & domestic/foreign & 7.15 & .01 \\
\cline { 2 - 4 } & life/non-life & 4.09 & .01 \\
\hline \multirow{2}{*}{ Integration } & domestic/foreign & 9.45 & .00 \\
\cline { 2 - 4 } & life/non-life & .70 & .55 \\
\hline
\end{tabular}

Source: Own Table based on the results of ANOVA run in SPSS 
In order to test whether there is a significant difference between domestic and foreign insurers and between life and non-life insurers in their belief in the level of harmonization of the Turkish insurance market with the European single insurance market, one-way ANOVA is carried out to compare the groups of domestic and foreign insurers and the groups of life and non-life insurers. There is not a significant difference in the belief in the level of harmonization of the Turkish insurance market with the European single insurance market between domestic insurers $(M=3.63 ; S D=.31)$ and foreign insurers $(M=3.66 ; S D=.24), F(1,50)=.77$, ns and also between life insurers $(M=3.64 ; S D=.23)$ and non-life insurers $(M=3.65$; $S D=.31), F(1,45)=.72$, ns. The fact that the survey reveals that being from life or non-life insurer does not matter in the belief in harmonization may be attributed to the findings of this study which indicate that the level of harmonization does not differ between life and non-life insurance markets.

In order to test whether there is a significant difference between domestic and foreign insurers and between life and non-life insurers in their belief in the benefits of the integration of Turkish insurance market with the European single insurance market when Turkey becomes member of the EU, one-way ANOVA is carried out to compare the groups of domestic and foreign insurers and the groups of life and non-life insurers. There is a significant difference between domestic and foreign insurers in their belief in the benefits of the integration of Turkish insurance market with the European single insurance market. Foreign insurers $(M=3.57 ; S D=.31)$ turn out to have a stronger belief in the benefits of the integration more than domestic insurers do $(M=3.37 ; S D=.37), F(1,50)=7.15, \mathrm{p}<.01$. It can thus be concluded that Turkish insurance sector supposes that the membership of Turkey to the EU would be more beneficial to foreign insurers operating in Turkey than domestic insurers.

There also exists a significant difference between life and non-life insurers in their belief in the benefits of the integration of Turkish insurance market with the European single insurance market. Non-life insurers $(M=$ 3.57; $S D=.37$ ) turn out to have a stronger belief in the benefits of the integration more than life insurers do $(M=3.46 ; S D=.20), F(1,45)=$ $4.09, \mathrm{p}<.01$. It can thus be concluded that Turkish insurance sector supposes that the membership of Turkey to the EU would be more beneficial to non-life market than life market. 
In order to test whether there is a significant difference between domestic and foreign insurers and between life and non-life insurers in their belief in the realization of the integration between the Turkish insurance market and the European single insurance market when Turkey becomes a member of the EU, one-way ANOVA is carried out to compare the groups of domestic and foreign insurers and the groups of life and non-life insurers. There is a significant difference between domestic and foreign insurers in their belief in the realization of the integration between the Turkish insurance market and the European single insurance market when Turkey becomes a member of the EU. Foreign insurers $(M=3.18 ; S D=.49)$ turn out to have a stronger belief in the realization of the integration more than domestic insurers do $(M=2.80 ; S D=.35), F(1,50)=9.45, \mathrm{p}<.01$. However, there is not a significant difference in the belief in the realization of the integration between life insurers $(M=2.92 ; S D=.56)$ and non-life insurers $(M=3.11 ; S D=.44), F(1,45)=.55$, ns.

Furthermore, descriptive analyses give more detailed results about the perceptions on the harmonization process, expectations on the likelihood of different types of benefits and costs of the integration and expectations on the market entry strategies of the EU and Turkish insurers.

Perceptions of the Turkish insurance sector on the harmonization level of different areas of insurance legislation with the EU acquis are reported in Graph 1. Managers in the Turkish insurance sector believe that supervisory requirements $(78 \%)$ as well as the rules on technical reserves $(88 \%)$, financial reporting $(80 \%)$, insurance intermediaries $(69 \%)$, life insurance $(67 \%)$ and solvency requirements $(58 \%)$ are harmonized with the EU rules to a great extent. These perceptions are in line with the findings of the comparative analysis made in this study on insurance legislation of Turkey and the EU that although there are still areas to be further harmonized, Turkish insurance legislation is harmonized with the EU insurance acquis to a great extent.

The abstention in the perception of the level of harmonization in MTPL insurance is high mainly due to non-responsive participants from life insurers. Those who responded are mostly of the opinion that MTPL insurance is not harmonized with the EU rules. The perceptions are in line with the findings of this study that most of the requirements of Directive 2009/103/EC on motor insurance such as minimum cover limits, cover of 
material damages of uninsured vehicles should be gradually aligned with the EU acquis.

Mixed conclusions can be drawn as to the perceptions about the level of harmonization of tariffs and licensing rules. Although the Turkish insurance market which was traditionally a highly regulated market has made big steps towards tariff liberalization, $42 \%$ of the respondents suppose that tariffs are not as liberalized as they are in the EU. The perceptions are again in line with the findings of this study that tariffs in compulsory insurances and in life insurance should be further liberalized in order to comply with the EU requirements.

$37 \%$ of the respondents think that the licensing requirements are aligned with the EU rules and 39\% of them think the opposite. The perception that licensing requirements are not harmonized with the EU rules is not in conformity with the findings of this study that licensing rules such as fit and proper requirements for founders and managers, scheme of operation to be submitted to authorities and taking-up capital per line of business are harmonized with the EU acquis. Since it is theoretically demonstrated in this study that licensing requirements are harmonized to a great extent, those who perceive a lack of harmonization in this area of legislation may just give their opinion taking into account the considerable amount of work and time to be spent in order to establish an insurer in Turkey. However, it does not mean that the rules are not harmonized. While the length of the establishment process may differ from one country to another or even from one company to another within a country, it does not mean that the establishment rules and procedures differ between countries. 
Graph 1: Perceptions on the Harmonization of the Turkish Insurance

Legislation with the EU Insurance Legislation (\%)

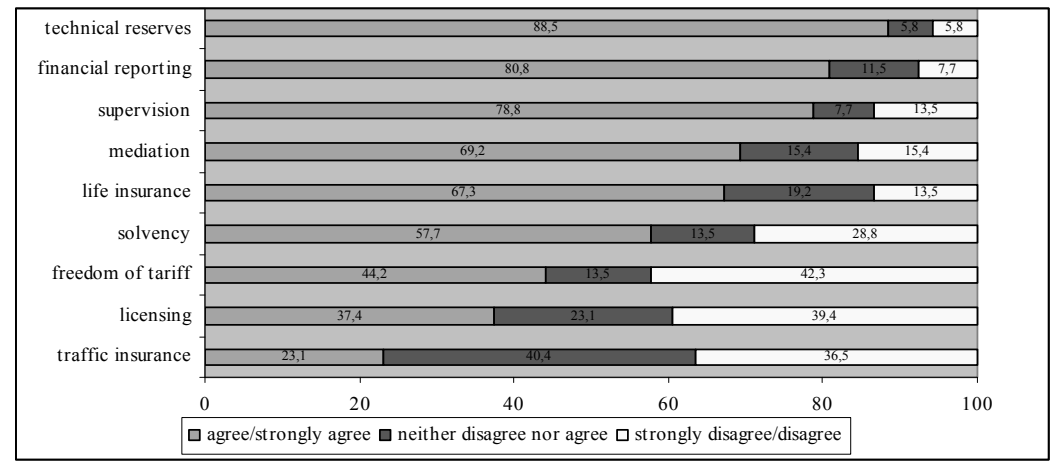

Source: Own Graph based on the results of the survey

Perceptions of the Turkish insurance sector on the changes in the behavior of insurers and policyholders during the harmonization process with the EU are illustrated in Graph 2. 94\% of the respondents think that corporate governance has become more important for the companies. $67 \%$ of the respondents think that organizational structure of the insurers has been restructured. This reflects the fact that $90 \%$ believe that workload has been considerably increased during the harmonization process. Moreover, $73 \%$ of the respondents also believe that the harmonization process is considerably costly for the entire sector.

$71 \%$ of the managers surveyed arrive at the opinion that insurers had to increase equity capital due to the harmonization process. Only $44 \%$ of them believe that claim payments have been accelerated during the harmonization process whereas $36 \%$ of them do not perceive any acceleration.

A great majority of the participants believe that the buying attitude of the policyholders has not been changed during the harmonization process. This result is in line with the general assumption that policyholders in Turkey still take into account the price of insurance products rather than their coverage in their buying decisions.

As to the perception about the reasons of the penetration of foreign insurers into the Turkish insurance market, there is not a widespread assumption in the sector that the harmonization process engenders foreign penetration. $48 \%$ of the participants think that one of the motivations of the penetration 
of the EU insurers into the Turkish insurance market is the alignment of the market with the EU requirements while $42 \%$ of them attach the EU insurers' penetration into the Turkish insurance market to other reasons than the harmonization process itself. The views of the participants are largely in line with the conclusions of this study that whereas the harmonization process affects the decisions of the EU insurers to enter the Turkish insurance market, political stability, macroeconomic results and growth potential of the sector are the main motivations behind the market entry decision of the EU insurers.

\section{Graph 2: Perceptions on the Changes in Turkish Insurance Market in its Harmonization Process with the EU (\%)}

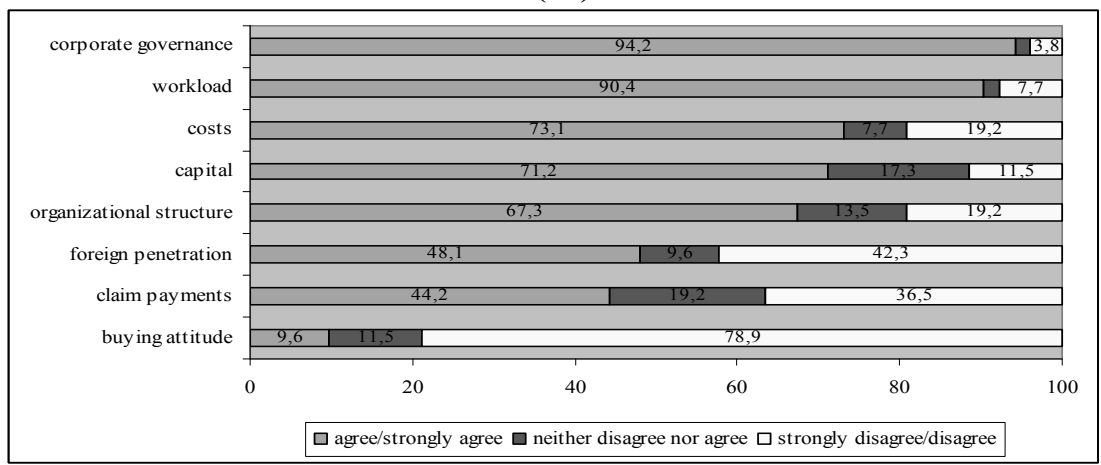

Source: own Graph based on the results of the survey

The respondents predict both positive and negative consequences for Turkish insurance market when Turkey becomes member of the EU. However, expected benefits seem to dominate expected costs. Graph 3 demonstrates the expectations on the benefits of the EU membership of Turkey for the Turkish insurance market. Participants are predominantly positive about the benefits of the membership of Turkey to the EU.

A great majority foresee an increase in life density $(80 \%)$, in non-life density (77\%) and in penetration (90\%). As a result of the expected increase in the volume of premiums, they also predict an increase in the assets of the companies (88\%) and in employment (75\%).

Although an increase in premium production is foreseen by the majority of the respondents, the increase in profitability is expected only by $44 \%$ of the respondents. The results can be interpreted as excessive price 
competition is expected to continue. Moreover, the decrease in reinsurance costs is not an expected result of the membership. Thus, increase in profitability is not foreseen by the majority of the respondents. The predictions on profitability are in line with the expectations of the EU insurers that were surveyed before the establishment of the single insurance market in 1994. The survey carried out by the Institute of Insurance Studies at Cologne University in conjunction with the Geneva Association in 1994 to investigate the expectations of the EU insurers on the European single insurance market revealed that $56 \%$ of the insurers anticipate decreasing profits in their countries of origin as a result of the increase in competition (Weidenfeld, 1996, p.88).

A clear majority of the respondents expect an increase in product differentiation in the sector (92\%) as a result of the membership of Turkey to the EU. Further liberalization as well as alignment with Solvency 2 requirements would enable the insurers to provide innovative products. In addition, new market entries in Turkish insurance market as a result of the EU membership of Turkey would also lead to product differentiation.

Furthermore, after membership of Turkey to the EU, in other words after full alignment of Turkish insurance market with the EU insurance acquis, the sector anticipates higher consumer protection (67\%) and higher consumer confidence $(73 \%)$. Higher consumer protection will naturally give rise to higher consumer confidence. However, since supervision of the insurers is considered to be harmonized with the EU rules, the reasons of the expected increase in consumer protection should be further analyzed. One reason may be the upcoming of the new solvency requirements which consist of risk-based capital requirement calculations and new rules on corporate governance and market discipline. Another reason may be the predicted increases in the assets and shareholders' equity of the companies that would make their financial structure stronger. 


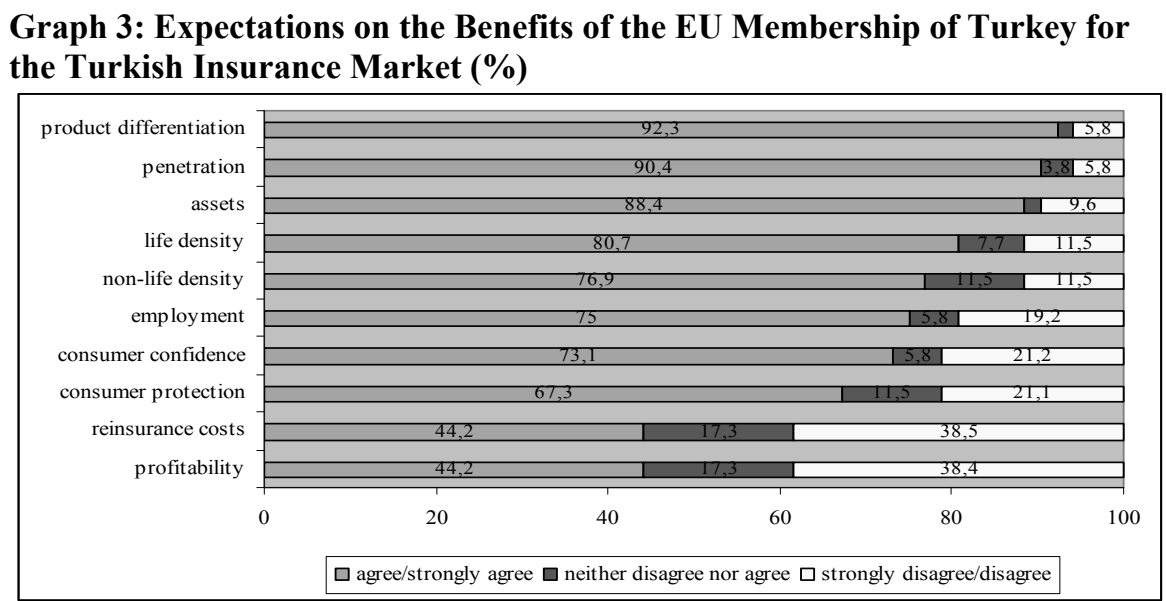

Source: own Graph based on the results of the survey

Graph 4 demonstrates the expectations on the costs of the EU membership of Turkey for the Turkish insurance market. Consolidation is the most important concern of the sector (71\%). In contradiction to this concern, only $46 \%$ of the respondents think that the Turkish insurance market will be faced with competition problems. Therefore, an important number of respondents attribute the reason of consolidation to other reasons than competition problems. Only $36 \%$ of the respondents anticipate insolvency problems in Turkish insurance market as a result of the EU membership of Turkey. Therefore, liquidation in the sector is not predicted by the majority of the respondents. However, EEA insurers were anticipating liquidation in the European insurance market as a result of third insurance directives, and thus higher level of concentration in the market (Weidenfeld, 1996: 88).

On the other hand, the majority of the respondents do not suppose any decrease in the price of insurance products $(58 \%)$ to the benefit of the consumers. They do not expect any reduction in prices since they largely believe that the prices are already considerably low due to excessive competition between the insurers. 


\section{Graph 4: Expectations on the Costs of the EU Membership of Turkey for the Turkish Insurance Market (\%)}

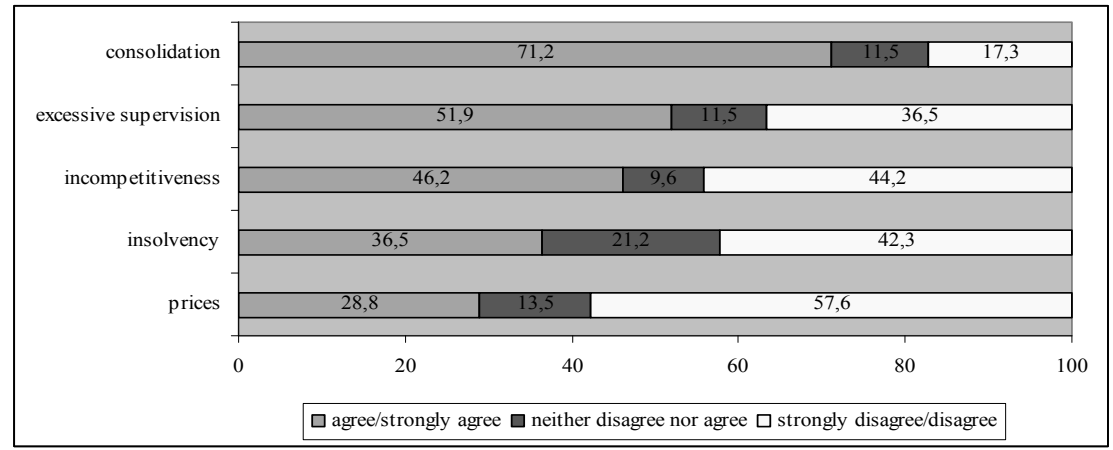

Source: own Graph based on the results of the survey

Graph 5 illustrates the expected market entry strategies of the EU insurers to the Turkish insurance market and of the Turkish insurers to the insurance markets of the EU Member States after the membership of Turkey to the EU. When Turkey becomes member of the EU, freedom of services is not expected to be used neither by the insurers in Turkey $(60 \%)$ nor by the EU insurers (77\%).

However, the respondents are optimistic about the use of FOE both by the insurers established in Turkey (62\%) and in the EU (60\%). The prospect for the success of FOE is thus estimated as considerably higher than the prospect for the success of FOS. These results are in line with the expectations of the EU insurers surveyed before the establishment of the single insurance market in 1994. Weidenfeld (1996: 85) reports that 52\% of the EU insurers was expecting an increase in the number of the EEA branches operating in their countries of origin as a result of third insurance directives and concludes that the internal insurance market would be effective not so much throughout Europe but rather between neighboring countries.

Majority of the respondents predict that Turkish insurers would be acquired by the EU insurers while partnership through acquisition of minority shareholding is not a predicted result. However, M\&A in Turkish insurance market, especially by the EU insurers, is already a given fact since 2006. Therefore, the process of M\&A in Turkish insurance market is not directly related to the EU membership of Turkey. In parallel, Atalay (2004: 
71) concludes that the single market principles are not the prerequisites of the establishment of foreign subsidiaries which are subject to the supervision of the Member State in which they are established, thus the increase in European insurance groups in the EU is not purely the result of the creation of the European single insurance market.

On the other hand, the participants are also surveyed about their expectations on the acquisition of the EU insurers by the insurers in Turkey. Taking into account the size of the insurers in Turkey, acquisition of the majority shareholding or minority shareholding of the EU insurers is not an anticipated result of the EU membership of Turkey.

\section{Graph 5: Expectations on Market Entry Strategies of the Insurers (\%)}

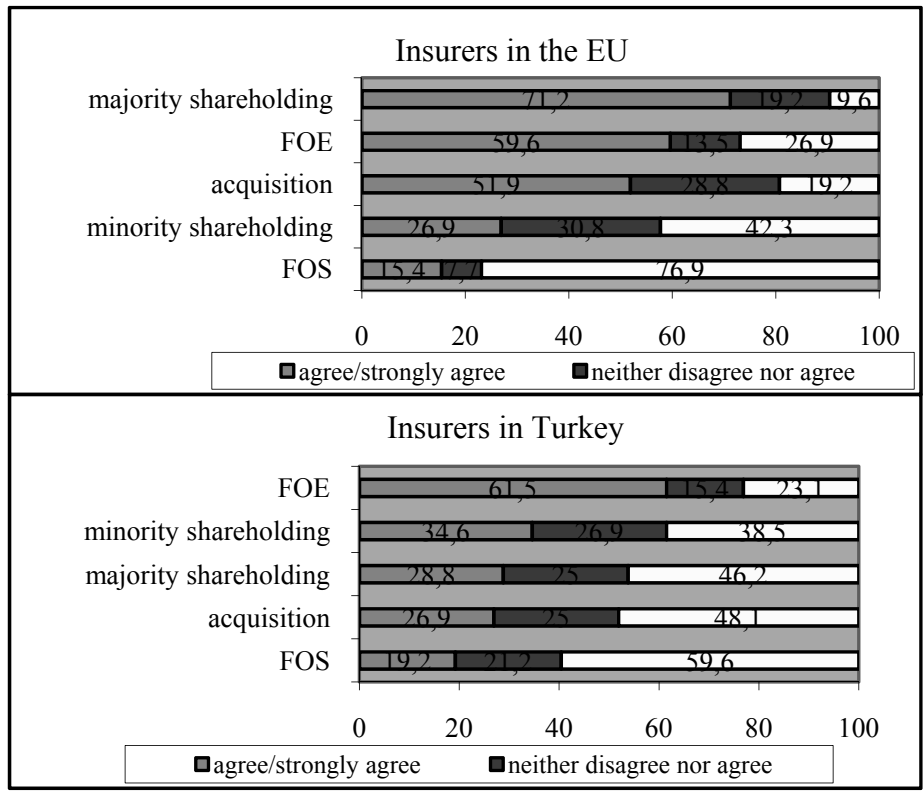

Source: own Graph based on the results of the survey

Expectations on the likelihood of different lines of business in which the EU insurers would intend to operate in Turkey are reported in Graph 6. Respondents believe that the EU insurers would operate mostly in life insurance market in Turkey (69\%). The underlying assumption behind this 
expectation would be that life insurance market in Turkey has a big growth potential and thus would attract foreign players from the EU.

Respondents from life insurers mostly preferred not to give any predictions on non-life insurance market. Those who gave a response suppose that the EU insurers would also penetrate into non-life insurance market in Turkey. However, interestingly enough, the majority of the respondents do not suppose a penetration into motor insurance market (neither MTPL nor casco) which is the biggest insurance market in Turkey. Motor insurance market is not profitable and due to high price competition, insurers bear large losses in this line of business. Therefore, foreign entries are expected in more profitable lines of business since growth potential and profitability are the main motivations behind foreign entries. Non-traditional non-life branches such as liability (other than MTPL), financial losses and legal protection would thus be more attractive to the EU insurers.

\section{Graph 6: Expectations on Lines of Business in which the EU Insurers Would Operate in Turkey}

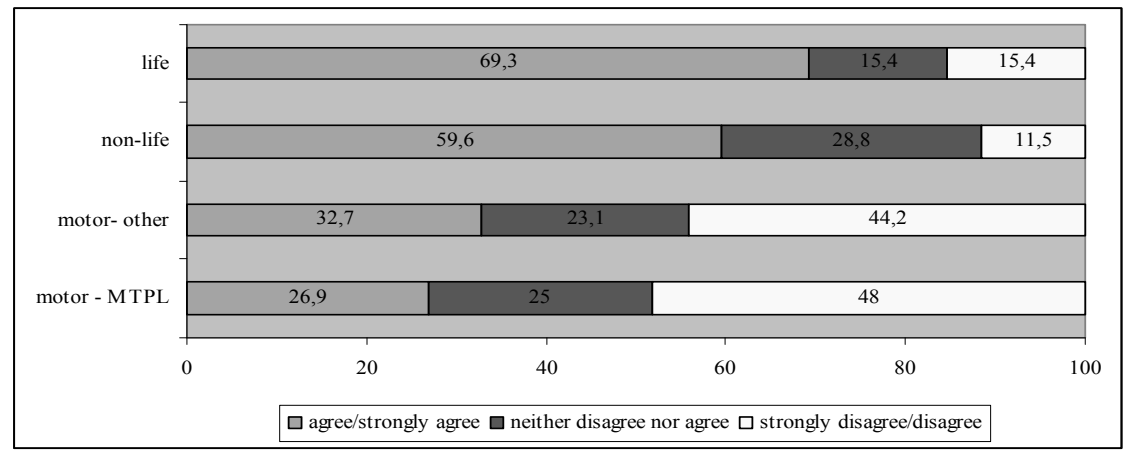

Source: own Graph based on the results of the survey

Graph 7 demonstrates the expectations on type of consumers who would buy insurance products directly from the insurers established in the EU. It is not expected that individual consumers in Turkey would buy insurance products from the insurers that are not established in Turkey. Therefore, it would not be meaningful to expect that the EU insurers would be able to directly sell their products to Turkish consumers through FOS.

However, the majority of the respondents $(75 \%)$ predict that corporate consumers would prefer to benefit from FOS when Turkish insurance 
market becomes part of the European single insurance market. The predictions are in line with the current situation in the EU where crossborder business through FOS in wholesale insurance market is higher compared to retail insurance market.

\section{Graph 7: Expectations on Type of Consumers Benefiting From FOS (\%)}

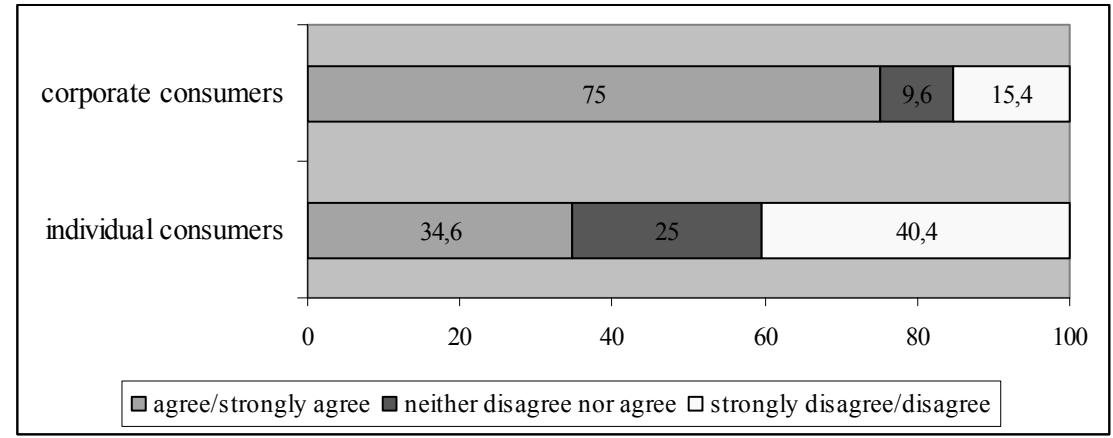

Source: own Graph based on the results of the survey

\section{Conclusion}

This paper claimed that cross border activities through FOS and FOE is restricted in the European single insurance market and thus the integration of the insurance markets of the EEA Member States are far from being completed. On the other hand, Turkey, a candidate country to the EU, harmonized its insurance legislation with the EU insurance acquis to a great extent during its harmonization process with the EU. The expectations of the managers in the Turkish insurance sector on the level of harmonization of the Turkish insurance market with the European single insurance market are investigated by a survey covered 52 managers from 33 different companies.

The perception of the sector is in line with the findings of this paper that although there are still areas to be further harmonized, Turkish insurance legislation is harmonized with the EU insurance acquis to a great extent. However, there is not a widespread assumption in the sector that the harmonization process is the main motivation behind the foreign penetration into the Turkish insurance market.

Turkish insurance sector believes that the membership of Turkey to the EU would be beneficial for the Turkish insurance market. Non-life insurers 
predict higher benefits than life insurers and foreign insurers predict higher benefits than domestic insurers. Increase in penetration, density, product differentiation, consumer protection and consumer confidence are predicted by the insurance sector. However, neither increases in profitability nor reductions in prices are anticipated results of the EU membership of Turkey. The sector believes that Turkish insurance market would not be faced with competition and insolvency problems. On the other hand, further consolidation is their most important concern.

Turkish insurance sector believes that the EU membership of Turkey would not result in the integration of the insurance markets. However, foreign insurers have a relatively stronger belief in the realization of the integration. While FOS is only expected to be used in wholesale insurance market, Turkish insurance sector is relatively more optimistic about the use of FOE. However, the general opinion of the sector is that M\&A will not be replaced by FOS and FOE, but will continue to be the dominant foreign market entry strategy even after the accession of Turkey to the EU. 


\section{References:}

Atalay, A. U. (2004). Avrupa Birliği Perspektifiyle Hizmetlerin Serbest Dolaşımı Kapsamında Türk Sigortacılık Sektörünün Değerlendirilmesi. Avrupa Birliği Genel Sekreterliği Uzmanlık Tezi. Ankara.

Beckmann, R., C. Eppendorfer and M. Neimke. (2002). Financial Integration within the European Union: Towards a Single Market for Insurance. MPRA Papers. 5280 .

Brittan, L. (1990). European Insurance in a Single Market, Tijdschrift voor Economie en Management. 35.4, 411-423.

Ellis, H. (1990). European Integration and Insurance. London: Witherby\&Co.

European Commission. (2007). Interim Report on Business Insurance Sector Inquiry. Brussels.

Hess, T. and T. Trauth. (1998). Towards A Single European Insurance Market. International Journal of Business. 3.1, 89-100.

Insurance Supervisory Board (ISB). (2010). 2009 Annual Report about Insurance and Private Pension Activities in Turkey.

Labilloy, B. (2003). European Insurance Regulation: New Opportunities for Insurers and Consumers. Brussels: CEA.

Skipper, H. D. (1997). Foreign Insurers in Emerging Markets: Issues and Concerns. IIF Occasional Papers. 1.

Weidenfeld, G. (1996). The European Internal Insurance Market: Expectations, Assessments and Consequences for Business Policy from the Insurers' Point of View. The Geneva Papers on Risk and Insurance. 21.1, 77-107. 